\title{
Impact of Welfare Facilities on Job Satisfaction of the Non- Executive Employees of XYZ Company in Sri Lanka
}

\author{
J. A. N. Shiroma ${ }^{1}$ and L. V. K. Jayatilake ${ }^{2}$ \\ ${ }^{1}$ HITEC Sensor Development (Pvt) Limited, Sri Lanka \\ ${ }^{2}$ Department of Commerce and Financial Management, \\ University of Kelaniya, Sri Lanka \\ Inishanthi_1493@yahoo.com, ${ }^{2}$ lakminij@kln.ac.lk
}

\begin{abstract}
The aim of this study is assessing the effect of welfare facilities to job satisfaction of the Non-Executives Level employees in XYZ Company in Sri Lanka. Their job satisfaction is depended on many factors. Among the factor's welfare facilities are important. This study as a part of investigates the effect of welfare facilities on the job satisfaction of Non-Executives Level employees in XYZ Company in Sri Lanka. The sample consists of 100 Non-Executive Level in the XYZ Company of Sri Lanka. The data collection was done by using a self-administrated structure questionnaire. The results indicated that medical facilities, canteen facilities, loan facilities and housing facilities variables were positively and significantly correlated with job satisfaction variable.
\end{abstract}

This study provides good evidence to take idea on their effectiveness of welfare facilities and take idea about whether employees are satisfied or not. Furthermore, the study of job satisfaction level of Non-Executives Level employees in XYZ Company the result will become the good measurement to an organization and make awareness about providing, enhancing welfare facilities to their employees. According to some of the previous studies, top level management pay little attention on this area of providing welfare facilities. That may be happened, due to unawareness about advantages of providing welfare facilities to employees. So, this study focused to find out impact of welfare facilities on job satisfaction and nature of perception of Non-Executives employees about their welfare facilities. This is an attempt to bridge the gap in the Sri Lankan empirical knowledge of the empirical factors of the job satisfaction of NonExecutives employees from their perception. Findings of this study can be used to enhance the job satisfaction employees who are working in other industries.

Keywords: Welfare Facilities, Job Satisfaction, Non-Executive Level Employees

\section{Introduction}

In today's business world human resource become the major resource in any kind of business. Because it has unique value when comparing with other resources. For that reasons important to manage human resource carefully than other resources. In lots of business Human Resource Management (HRM) is the most important functional field. "It has covered broad area of management. Further HRM deals with management of human resource in an organization. Also, it is human side of business administration" (Opatha, 2009). According to Opatha (2009) "HRM is 
effective and efficiently utilization of human resource in order to achieve common goal of organization". Normally, HRM consists of eighteen functions such as " job analysis, job design, human resource planning, recruitment, selection, hiring, induction, performance management, training and development, pay management, career management, welfare management, grievance management, health and safety management, industrial relation, employee movement management, disciplinary management" (Opatha, 2009) (opat, 2009) (Tiwari, 2014)

Also, employee welfare management is one of important functional area which comes under HRM. According to Opatha (2009) "employee welfare can be introduced as an important function of HRM. Employees do not work like machines. It is not possible to get works done through them just like getting thing done through machines. Generally, it is possible for an organization to obtain a maximum servicel contribution from them by fulfilling their basic need (or helping them to meet) and taking care of them in appropriate way". Hence, HRM function of employee welfare represents specialized tasks. Employee's welfare package helps for attract and retain suitable qualified employees for filling job vacancy and achieving organization's objectives. Finally, that leads to organization success and progress of success. Therefore, in competitive business world organization must spend considerable amount of money and other resource for that.

Employee welfare can be defined as "providing facilities and comforts to employee of an organization. So that they will be able to lead a better level of living" (Opatha, 2009). The concept of employee welfare has broad meaning. Also, Employees have enough knowledge about his/her rights. Therefore, today employees are more knowledgeable than past employees. They consider about indirect compensation packages. If organization has sufficient welfare package which helps for acquiring and retain suitable and qualified employees within an organization. Also, most of employees try to join with organization which is provided large number of welfare facilities. According to Opatha (2009) "HRM function of employee welfare should not be treat as a function of less importance. Though the organization has to spend a considerable amount of money and other resource employee welfare is often an investment that is conductive to organizational success and progress of success". Strategic reasons for offering benefits include attracting and retaining employees, improving the company's images, and enhancing job satisfaction (Armstrong, 1996).

According to Spector (1997) job satisfaction is simply how people feel about their jobs and different aspects of their jobs. And it is the extent to which people like (satisfaction) or dislike (dissatisfaction) their jobs. Locke (1976) mentioned that job satisfaction is a pleasurable or positive emotional state resulting from the appraisal of one's job and job experience. Azeem and Akhtar (2011) have mentioned that, issues such as high turnover rate, absenteeism, role conflict, job stress, burnout etc. are posing challenges for the organizations which are due to lack 
of job satisfaction and commitment among employees.

According to Parvin and Kabir (2011) "job satisfaction has been closely related with many organizational phenomena such as motivation, performance, leadership, attitude, conflict, moral etc. Researchers have attempted to identify the various components of job satisfaction, measure the relative importance of each component of job satisfaction and examine what effects these components have on employees' productivity".

The progress of a company and the development of the nation depend to a large extent on the welfare of the workers and their attitude towards work. Thus, employee welfare and job satisfaction assume importance (De Souza, 2009). Therefore, every organization tries to make and create their workforce more satisfied and mentioned, it will influence to the well-being of the organization. Therefore, this study is aimed to discuss the effect of welfare facilities on job satisfaction among NonExecutive level employees in the XYZ Company in Sri Lanka.

\section{Research Problem}

According to De Souza (2009) "The employee welfare measures provided in an organization affect the attitudes of employees towards work. Employee welfare facilities satisfy the needs of the employees, which can improve their working life, family life and overall welfare. Various studies by researcher (De Souza, 2009; Reddy, 2012) have explored the employee welfare facilities provided by organizations and determined its influence on job satisfaction. De Souza (2009) studied impact of employee welfare facilities on job satisfaction a comparative study of Indian pharmaceutical companies (IPCs) and multinational pharmaceutical companies (MPCs) in Goa. The results of the study revealed that the eight dimensions of employee welfare were positively and significantly correlated with job satisfaction. An increase in any of the employee welfare dimensions would significantly increase job satisfaction of employees in the pharmaceutical companies in Goa. If the pharmaceutical companies improve the welfare facilities of their employees, then the job satisfaction of their employees would greatly increase.

According to De Souza (2009) that indicated gender of employees showed no significant influence on the job satisfaction of the respondents in the pharmaceutical companies in Goa and a significant positive correlation existed between age and job satisfaction of employees in pharmaceutical companies in Goa. There was also a significant positive relationship between experience in the present job and the job satisfaction of employees in pharmaceutical companies in Goa. What is more, research could identify, there is positive correlation between welfare facilities and job satisfaction.

According to Satynarayan and Reddy (2012) has studied employee welfare measures in cement industries in India. The study was carried out to know the satisfaction levels of employees about employee welfare measures in $\mathrm{KCP}$ limited (Cement Division). Sample 
consist of 90 employees. This study has found out that "most of respondent satisfied with all welfare facilities provided by organization such as transport facilities, medical facilities, drinking water, rest and lunchroom, sports and recreational facilities, children education facilities, housing facilities, leave travel concessions, special medical aid facilities and retirement benefits. There were $25 \%$, $45 \%$ of the respondents are highly dissatisfied with the Productivity linked annual bonus and consumer cooperative stores provided by the organization. There were $55 \%, 60 \%$ minimum number of the respondents are moderately satisfied with the subsidized canteen food and supply of uniforms provided by the organization" (Satynarayan \& Reddy, 2012).

\section{Objectives of the Study}

This study attempts to achieve following objectives.

i. To identify the determinants of welfare facilities of Non-

Executives Level employees in XYZ company in Sri Lanka.

ii. To assess how welfare facilities effect of job satisfaction NonExecutives Level employees in XYZ company in Sri Lanka.

\section{Research Gap}

Welfare facilities mean broad area to discuss. It varies to organization to organization. Providing welfare facilities very important to retain and maintain contended workforce within the organization. It increases the employee's job satisfaction. According to De Souza (2009) studied regarding effect of employee welfare facilities on job satisfaction a comparative study of Indian pharmaceutical companies and multinational pharmaceutical companies in Goa. Jiskani et al (2011) explained how to measure job satisfaction level of government sector employees. A case of Bureau of Statistics, Government of Sindh, and Pakistan, Satynarayan and Reddy (2012) studied employee welfare measures in cement industries in an India which has find out that there is positive correlation between welfare facilities on job satisfaction to different industries. However, there is a gap in the empirical knowledge available, especially in Sri Lanka with regarded to the effect of welfare facilities on job satisfaction.

This gap exists especially in most of companies in Sri Lanka. Also, the importance of the study is that the selected organization has not undertaken any research study in welfare facilities and job satisfaction. Therefore, the problem of this study is.

"What is the effect of welfare facilities on job satisfaction of Non-Executives in XYZ Company in Sri Lanka?"

\section{Methodology}

The type of this study is analytical. The main objective of this study is to identify the effect of welfare facilities on job satisfaction among NonExecutives employees Thus, welfare facilities considered as independent variable and job satisfaction considered as dependent variable of this study.

Unit of analysis is an individual level (Non-Executives). The time horizon is cross sectional where data collection is done once. The target population of study is all Non-Executives in who are 
presently working in XYZ Company in Sri Lanka. The total populations of Non-Executives are 100. This study considered universal sampling method for selection of a sample. As a result, 100 Non-Executives are selected as sample.

Primarily researcher was used Quantitative research methodology. Firstly, this study developed a standard questionnaire to measure all the variables relevant to the study by adapting existing scales. The questionnaire was close ended, and respondents rated their agreement with each item on a five-point Likert scale, ranging from strongly disagree (1) to strongly agree (5). Before conducting the main survey, pilot tested with 25 respondents and checked reliability and different types of validity. The secondary data collected from the various sources such as organization report, books, journals, government reports, internet, and other publications.

The statistical technique for data analysis includes descriptive statistics (mean, mode and median), univariate, bivariate multivariate methods, which would be completed by 23 . Further, hypotheses of the study are measured through Pearson Product Moment Correlation Technique and Simple Regression Techniques.

\section{Studies on Employee Welfare Facilities}

Welfare measures relates to certain additional activities which are provided by an organization like housing facilities, transportation facilities. Medical facilities, recreational and cultural facilities, libraries, gym and health club etc in hope of winning the satisfaction index of an employee McGuire and McDonnel (2008) suggested that the welfare facilities aid in enhancing the self-confidence and intellectual level of an employee. Torjman 2004 demonstrated that welfare facilities and recreation accounts for healthy individual besides encashing among their happiness and emotional quotient. Kirsch (2009) believed welfare facilities should be flexible and continuous innovation needs to be done. Pinder, Mathew (2011) advocated that employee welfare measures serve as an oxygen for motivation of the workers and increasing the effectiveness of the workforce.

Previous scholars defined the employee welfare facilities in difference ways. According to Schuler (1981) welfare facilities defined as an indirect compensation. In addition, he mentioned about almost all organization offer some form of indirect compensation- also known as fringe benefits or supplemental compensation. Further, explained welfare facilities as, "anything done for the comfort and improvement, intellectual and social, of the employees over and above the wages paid, which is not a necessity of the industry" (Punekar et al, 2004).

According to the Jyothi (2012) welfare facilities are a broad concept referring to a state of living of an individual or a group, in a desirable relationship with the total environment-ecological, economic, and social. The term 'welfare facilities' includes both social and economic contents of welfare. 
Puja and Sanjeev (2014) welfare facilities are a desirable state of existence involving for certain components of welfare, such a health, food, clothing, and housing, medical assistance, insurance, education, recreation, job security, and so on. The word employee means any productivity activity. In a broader sense, therefore, the phrase employee welfare means the adoption of measures to promote the physical, social, psychological, and general wellbeing of the working population. Welfare work in any industry aims, or should aim, at improving the working and living conditions of workers and their families.

It is defined as a wide range of socially and economically sponsored activities and programmes either by individual groups, government and which are directed to enhance life and promote wellbeing of populace to live their life fully, purposefully, and meaningfully (Nigerian Scholar) Olowa Y. (2012)

Wilensky and Lebeaux (1965) added that every industrial system require some competition for occupational position, on the basis of skills relevant to the task, as well as some system of special reward for scarce talents and skills, in the same vein Schultz (1970) stated that adequate compensation for service lies at the heart of motivation for most people because, a professionally trained individual can earn a "decent living" furthermore, Gardiner and Judd (1959) postulated that employer have to play a great part in providing benefits (package). They believed enlightened policies give workers dignity and status as part of an industrial unit to help them to realize the essential new fact of existence that everyone depends on everyone else.

a professionally trained individual can earn a "decent living" furthermore, Gardiner and Judd (1959) postulated that employer must play a great part in providing benefits (package). They believed enlightened policies give workers dignity and status as part of an industrial unit to help them to realize the essential new fact of existence that everyone depends on everyone else.

Wilensky and Lebeaux (1965) added that every industrial system require some competition for occupational position, on the basis of skills relevant to the task, as well as some system of special reward for scarce talents and skills, in the same vein Schultz (1970) stated that adequate compensation for service lies at the heart of motivation for most people because, a professionally trained individual can earn a "decent living" furthermore, Gardiner and Judd (1959) postulated that employer have to play a great part in providing benefits (package). They believed enlightened policies give workers dignity and status as part of an industrial unit to help them to realize the essential new fact of existence that everyone depends on everyone else.

Mayo (1945), Mc Gregor (1960) also supported that foregoing position in their positon that there is need for human co-operation so that both the individual and organization goal might be achieved. According to them, human co-operation is needed in such area as leadership style, decision making, planning group approval and recognition, and welfare of workers. This is necessary because, organization collectively in decision making and 
promoting harmonious relationship between workers and management on one side and worker on the other side.

Owen (1913) attached great importance to worker welfare. He opined that worker should focus on decent hearth facilities in the factories. Also, that the worker is a vital machine on whom much attention should be devoted by employer. He believes that it is mainly in this way that maximum profits could be achieved. According to hi workers are like children needing such careful handling and that healthy intelligent worker produce more than debilitated ones and that bad condition militate against efficiency and productivity.

\section{Conceptual Framework}

According to Sekaran (2006) the conceptual framework makes logical sense of the relationship among the several factors that have been identified as important to research problem area. Considering prevailing literature this study primarily considers two main variables as independent and dependent. Figure 1 graphically shows the dependent and independent variables of this study.

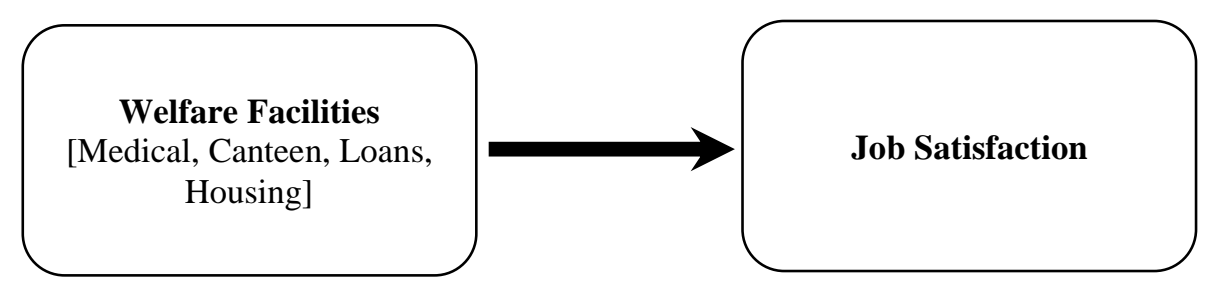

Figure 1: Conceptual Framework

Source: Authors, 2021

The independent variable is employee welfare facilities consisting of four dimensions as medical facilities, canteen facilities, housing facilities and loan facilities (refer Figure 1). The dependent variable is job satisfaction. Ex: consisting of five dimensions. Such as work itself, rewards, supervisions, co-worker, promotions, and training opportunities (refer Figure 1).

\section{Hypotheses of the Study}

Considering the variables depicted in the conceptual framework (Figure 1) and existing literature following hypotheses are developed.

\section{Medical Facilities and Job Satisfaction}

According to Satyanarayana and Reddy (2012) there is a positive impact (4.4 average mean value and $85 \%$ ) of medical facilities and job satisfaction. Further, Salaria and Salaria (2013) explained medical facilities impact on job satisfaction in auto mobile industry in India. Furthermore, they analyzed data and explained $40 \%$ of employees are satisfied with the medical facilities, $56 \%$ of employees have moderately satisfied and $4 \%$ of employees are dissatisfied. Accordingly, hypothesis one is develop as: 
Hypothesis $1\left(\mathrm{H}_{1}\right)$ : Medical facilities will impact on job satisfaction of NonExecutives Employees

\section{Canteen Facilities and Job Satisfaction}

According to Salaria and Salaria (2013), canteen facilities impact on job satisfaction of employees. They found that $86 \%$ employees satisfied, $8 \%$ moderately satisfied and $6 \%$ employees are dissatisfied with canteen facilities. Also, Prabakar (2013) explained his study that $55.56 \%$ of the employees are highly satisfied, $22.22 \%$ are satisfied and $22.22 \%$ are not satisfied with the existing canteen facilities. However, Satyanarayana and Reddy (2012) described that employees are moderately satisfied with existing canteen facilities. Thus, second hypothesis of this study develop as:

Hypothesis 2 (H2): Canteen facilities will impact on job satisfaction of NonExecutives Employees

\section{Loans Facilities and Employee Job Satisfaction}

As organization they must provide loans facilities to employees. According to De Souza (2009) found that subsidized loan facilities impact on job satisfaction that there is positively and significantly correlated between subsidized loans facilities and job satisfaction. So, third hypothesis of this study is developing as:

Hypothesis $3\left(\mathrm{H}_{3}\right)$ : Loan facilities will impact on job satisfaction of Non Executives Employees.

\section{Housing Facilities and Job Satisfaction}

Housing facilities is another type of welfare facility which is essential to any one as human being. Housing means providing house for employees to live in or provision of accommodation. When concerning about how housing facilities effect on level of job satisfaction of employees. Satyanarayana and Reddy (2012) have found out that $80 \%$ of target respondents are satisfied with existence housing facility. Its weight average mean value is 4.4. So, majority of employees satisfy with housing facilities provided by organization. Therefore, there is positive relationship with housing facility and level of job satisfaction. Thus, the third hypothesis for this study that was developed as.

Hypothesis 4 (H4): Housing facilities will impact on job satisfaction of NonExecutives Employees.

\section{Bivariate Analysis}

The Bivariate Analyses included the Correlation Analysis and the Simple Regression Analysis, which were used to investigate any relationship between each of the independent variable (Employee welfare facilities) and the dependent variable of job satisfaction.

\section{Employee Welfare Facilities and Job Satisfaction}

\section{Correlation Analysis}

To test the correlation between variables the Pearson product movement correlation coefficient and one-tailed test was used. It is the most often used parametric correlation measure when dealing with simple 
information summarizing statistics, which represent the linear relationship between two set of variables. The Pearson correlation can be meaningfully for variable measured on interval and ratio sales. Also, the Pearson correlation indicates the direction of the variables. The correlation co-efficient is identified by symbol " $r$ ". The correlation analysis was made to investigate relationship between employee welfare facilities and job satisfaction.
According to the results of the Pearson's correlation shown in the Table 1. There was a positive significance between employee welfare facilities and job satisfaction of the Non-Executives employees in XYZ Company Manufacturing Industry. The Pearson correlation between the two variables of Non-Executives was 0.593 which is positive. It shows that there was a positive relationship between employee welfare facilities and job satisfaction. Also, the found relationship is statistically significant at 0.01 levels (1- tailed).

Table 1: Correlations between Employee Welfare Facilities and Job Satisfaction

\begin{tabular}{|l|l|c|c|}
\hline \multicolumn{2}{|l|}{ Variable } & Welfare & Job Satisfaction \\
\hline \multirow{3}{*}{ Welfare } & Pearson Correlation & 1 & .593 \\
\cline { 2 - 4 } & Sig. (1-tailed) & & .000 \\
\cline { 2 - 4 } & $\mathrm{N}$ & 100 & 100 \\
\hline
\end{tabular}

\section{Regression Analysis}

In addition, Regression Analysis was done to discover the impact of welfare facilities on job satisfaction. According to the Table 2 of model summary, value of adjusted $\mathrm{R}$ square is 0.476 , depicting that job satisfaction is explained by $47.6 \%$ through variation in welfare facilities.

\section{Table 2: Model Summary}

\begin{tabular}{|l|r|r|r|r|}
\hline Mode & \multicolumn{1}{|c|}{$\mathrm{R}$} & $\begin{array}{c}\text { R Square } \\
\left(\mathrm{R}^{2}\right)\end{array}$ & $\begin{array}{c}\text { Adjusted } \mathrm{R} \\
\text { Square }\left(\mathrm{R}^{2}\right)\end{array}$ & $\begin{array}{c}\text { Std. Error of } \\
\text { the Estimate }\end{array}$ \\
\hline 1 & $.563^{\mathrm{a}}$ & .342 & .476 & .48332 \\
\hline
\end{tabular}

a. Predictors: (Constant), Welfare facilities

b. Dependent Variable: Job satisfaction

\section{Hypotheses Testing}

The hypothesis was carried using the results of Pearson's product Movement Correlation analysis and the results of Regression analysis as all hypothesis were concerned with a positive relationship and impact on one tailed was used. 
Testing Hypothesis 1 - Medical facilities impact on job satisfaction of Non-Executives in XYZ Company Manufacturing Industry

H1: Medical facilities will impact on job satisfaction of Non-Executives in XYZ Company Manufacturing Industry; ( $r>0 ; b>0)$.

\section{Correlation Analysis of H1}

According to Table 3, the results of Pearson's product Movement Correlation analysis between medical facilities and job satisfaction of NonExecutives employees in XYZ Company Manufacturing Industry. The correlation coefficients were 0.355 which was significant at $1 \%(\mathrm{p}=0.000)$.

\section{Regression Analysis of H1}

As per results of the Simple Regression Analysis between the medical facilities and job satisfaction, the regression coefficient (b) was 0.355 , which was significant at $1 \%($ Sig.T $=0.000)$.

Therefore, according to the results of both tests, The H1:1 Hypothesis was accepted since $r>0$ and $b>0$. Hence, the data support the hypothesis that medical facilities will effect on job satisfaction of Non-Executives employees in XYZ Company Manufacturing Industry.

Table 3: Correlation between Medical Facilities and Job Satisfaction

\begin{tabular}{|l|l|r|r|}
\hline & & Medical facilities & \multicolumn{1}{|c|}{ Job Satisfaction } \\
\hline \multirow{4}{*}{ Medical Facilities } & Pearson Correlation & 1 & $.355^{* *}$ \\
\cline { 2 - 4 } & Sig. (1-tailed) & & .000 \\
\cline { 2 - 4 } & $\mathrm{N}$ & 100 & 100 \\
\hline
\end{tabular}

Testing Hypothesis 2 - Canteen facilities impact on job satisfaction of Non-Executives in XYZ Company Manufacturing Industry

$\mathrm{H} 2$ : Canteen facilities will impact on job satisfaction of Non-Executives in XYZ Company Manufacturing Industry $(r>0 ; b>0)$.

\section{Correlation Analysis of $\mathbf{H 2}$}

According to Table 4, the results of Pearson's product Movement Correlation analysis between Canteen facilities and job satisfaction of NonExecutives employees in XYZ Company Manufacturing Industry The correlation coefficients was 0.413 which was significant at $1 \%(\mathrm{p}=0.000)$.

\section{Regression Analysis of $\mathrm{H} 2$}

According to results of the Simple Regression Analysis between the canteen facilities and job satisfaction, the regression coefficient (b) was 0.413 , which was significant at $1 \%$ (Sig. $\mathrm{T}=0.000)$.

Therefore, according to the results of both tests, The H2: Hypothesis was accepted since $r>0$ and $b>0$. Hence, the data support the hypothesis that canteen facilities will effect on job satisfaction of Non-Executives in XYZ Company Manufacturing Industry 
Table 4: Correlation between Canteen Facilities and Job Satisfaction

\begin{tabular}{|l|l|r|r|}
\hline & & Canteen Facilities & Job Satisfaction \\
\hline \multirow{4}{*}{ Canteen Facilities } & Pearson Correlation & 1 & $.413^{* *}$ \\
\cline { 2 - 4 } & Sig. (1-tailed) & & .000 \\
\cline { 2 - 4 } & $\mathrm{N}$ & 100 & 100 \\
\hline
\end{tabular}

Testing Hypothesis 3 - Loan facilities will impact on job satisfaction of Non-Executives in XYZ Company Manufacturing Industry

H3: Loan facilities will impact on job satisfaction of Non-Executives in XYZ Company Manufacturing Industry $(r>0 ; b>0)$.

\section{Correlation Analysis of $\mathbf{H 3}$}

According to Table 5, the results of Pearson's product Movement Correlation analysis between loan facilities and job satisfaction of NonExecutives employees in XYZ Company Manufacturing Industry. The correlation coefficients were 0.450 which was significant at $1 \%(\mathrm{p}=0.000)$.

\section{Regression Analysis of $\mathrm{H3}$}

Also, when considering about the results of the Simple Regression Analysis between the loan facilities and job satisfaction, the Regression coefficient (b) was 0.450 , which was significant at $1 \%$ (Sig.T=0.000).

Therefore, according to the results of both tests, The H:3 Hypothesis was accepted since $r>0$ and $b>0$. Hence, the data support the hypothesis that loan facilities will effect on job satisfaction of Non-Executives in XYZ Company Manufacturing Industry.

Table 5: Correlations between Loan Facilities and Job Satisfaction

\begin{tabular}{|l|l|r|r|}
\hline & & Loan facilities & \multicolumn{1}{|c|}{ Job Satisfaction } \\
\hline \multirow{4}{*}{ Loan Facilities } & Pearson Correlation & 1 & $.450^{* *}$ \\
\cline { 2 - 4 } & Sig. (1-tailed) & 100 & .000 \\
\cline { 2 - 4 } & $\mathrm{N}$ & & 100 \\
\hline
\end{tabular}

Testing Hypothesis 4 - Housing facilities impact on job satisfaction of Non-Executives in XYZ Company Manufacturing Industry

H4: Housing facilities will impact on job satisfaction of Non-Executives in XYZ Company Manufacturing Industry $(r>0 ; b>0)$.

\section{Correlation Analysis of $\mathbf{H 4}$}

According to Table 6, that indicated the results of Pearson's product Movement Correlation analysis between advance and housing facilities and job satisfaction of Non-Executives employees was 0.294 which was significant at $1 \%(\mathrm{p}=0.000)$. 


\section{Regression Analysis of $\mathbf{H 4}$}

Also, when considering about the results of the Simple Regression Analysis between the advance and housing facilities and job satisfaction, the regression coefficient (b) was 0.294 , which was significant at $1 \%$ (Sig.T=0.000).
Therefore, according to the results of both tests, The H: 4.was accepted since $\mathrm{r}>0$ and $\mathrm{b}>0$. Also, the coefficient 0.294 that indicate moderate positive relationship between housing facilities and job satisfaction. Therefore, the results support the hypothesis that housing facilities will positively effect on job satisfaction of Non-Executives in XYZ Company Manufacturing Industry.

Table 6: Correlation between Housing Facilities and Job Satisfaction

\begin{tabular}{|l|l|r|r|}
\hline & & Housing Facility & \multicolumn{1}{|c|}{ Job Satisfaction } \\
\hline \multirow{3}{*}{ Housing Facility } & Pearson Correlation & 1 & $.294^{* *}$ \\
\cline { 2 - 4 } & Sig. (1-tailed) & & .000 \\
\cline { 2 - 4 } & $\mathrm{N}$ & 100 & 100 \\
\hline
\end{tabular}

\section{Discussion of Findings}

This study mainly addressed to what extent the existence welfare facilities impact on job satisfaction of NonExecutives employees in $\mathrm{XYZ}$ Company Manufacturing Industry. Therefore, it is important to identify and prove that is there positive or negative impaction of employee welfare facilities on job satisfaction.

According to data analysis result (chapter four), it was found out that there is a positive relationship between employee welfare facilities and job satisfaction. The correlation between both two variables of Non-Executives employee was 0.593, which was significant at 0.000 levels. This correlation was lower bound of strong correlation (0.5). So, it was found out that the correlation was to be strong.

The results presented by Simple Regression Analysis, there is positive impact of employee welfare facilities on job satisfaction of Non-Executives employees in XYZ Company Manufacturing Industry. Because there was strength $b$ value of 0.593 . Hence, employee welfare facilities will predict job satisfaction of Non-Executives employees in XYZ Company Manufacturing Industry.

When considering about level of job satisfaction of the target sample of Non-Executives employees, it was found that there was favorable level of job satisfaction. Job satisfaction consisted with mean value of 2.8308 and standard deviation of 0.32819 with regarded of Non-Executives employees. Hence, it was revealed that the Non-Executives employees in XYZ Company Manufacturing Industry were satisfied with their jobs.

There are several researches which have expressed a number of finding relating to employee welfare facilities and job satisfaction. According to De Souza (2009), the Correlation and 
Regression Analysis provide sufficient statistical evident which were supported the relationship between employee welfare facilities and job satisfaction. Madumathi \& Desai (2003) has said that increasing employee efficiency, employee productivity and avoid the industrial dispute which can be gain through providing welfare facilities to employee. So, the research found out that when increasing labor welfare expenditure under the pressure and changing relationship between employer and employees.

According to Satynarayan \& Reddy (2012) have identified that "considerable level employees satisfied with existence welfare facilities granted by organization such as medical facilities, rest and Lunchroom, transport facilities, sports, drinking water and recreational facilities. Hence, welfare facilities are significantly impact on both organization and employees. Also, Luddy (2005) has identified that employee is most satisfied with the interpersonal relation with their colleges, followed by the work itself and the relation with supervisor.

As indicated by the empirical data, the level of job satisfaction of NonExecutives employees in XYZ Company Manufacturing Industry depended on the employee welfare facilities. The employee welfare facilities of the Non-Executives employees in XYZ Company Manufacturing Industry were satisfactory. Also, their job satisfaction was satisfactory. According to behavior of these two variables, the correlation between these two variables is significant. It means that work itself, reward, promotions and training opportunities, supervision, and coworker of Non-Executive employees in XYZ Company Manufacturing Industry were enhanced by the medical facilities, canteen facilities, loan facilities and housing facilities (Dimension of employee welfare facilities).

\section{Conclusion and Implications}

Based on the findings of the study the following recommendations were made which could be extremely useful for the XYZ Company Manufacturing Industry for improving the labor welfare facilities and the level of job satisfaction of Non-Executives employees and total employees in further. These recommendations are as follows:

First, the management should identify individual needs and values before designing the giving priority. whatever is offered as welfare provision would fail to attain such motivating goal.

Second, this derives from first recommendation that future researchers should be focused along the needs, perception of industrial workers and its effect on welfare facilities.

Third, it is also recommended that the income of the employees be periodically reviewed to meet current trend and demand of the economic, so that they would be willing to put more efforts toward increase productivity. This is necessary because periodic reviewed of income makes workers to be satisfied with their works.

Fourth, researcher can be directed on the effect of group work on the workers satisfactorily and interest in their job. 
Fifth, one area the company should address is the attention to the training of it is employee. Although, workers are given some training within the company to meet the company's needs, also, worker that have served the company for stipulated years and that have gained admission into higher institution should be assisted either by sponsoring them or given them school leave allowances. This is necessary because there is no worker in this company that is enjoying or has enjoyed this welfare provision from this company.

Lastly, the management should embark on a sincerer participative management style which will allow workers to participate in decisions. This will let the workers know the strength and the weakness of the company, this will give them a sense of belonging and make them to satisfy with their work.

\section{References}

Armstrong, M. (1996). A handbook of personal management practice. London: Kogan page limited.

Azeem, F. and Akhtar, S. H. (2011). The impact of different factors on teaching competencies at secondary level in pakistan. Interdisciplinary Journal of Contemporary Research in Business, 3(5):648-655.

De Souza, C. A. M. (2009). The employee well fare and job satisfaction: A comparative study of Indian pharmaceutical companies and multinational pharmaceutical companies in Goa. Doctoral dissertation. Goa: Khandola.

Jiskani, S. N., Bhatti, K. U. R. and Ahemed, S. (2011). Measuring Job Satisfaction Level of Government Sector Employees. Pakistan: Government of Sindh.

Schuler, R. S. (1981). Personnel and human resource management. St paul: West publishing company.

Schultz, G.P (1970), The logic of health care facility planning, Socio-Economic Planning Sciences, Volume 4, Issue 3, pp 383-393.

Jyothi, B.S. (2012). Employee Job Satisfaction in Software and ITeS units in Bangalo. An Empirical Study Business Management Dynamics, 3(6):46-55.

Kirsch (2009), Keys to employee satisfaction: What you can do to increase employee satisfaction, Http://humanresources.about.com?od?employeesatisfaction/a/ employee satisfaction.htm

Locke, E. A. (1976). The nature and causes of job satisfaction. Handbook of industrial and organizational psychology. Chicago: Rand McNally.

Luddy N. (2005). Job Satisfaction amongst employee at a public health institution, Western cape: University of the Western Cape. 
Madumati, M. and Desai, R.G. (2003). Analysis of pre and post reform social security and employee welfare expenditures in Karnataka state road Transport Corporation. Indian journal of industrial relation, 38(4).

Mayo E (1945), The social problems of an industrial civilization, London, Routledge and Kegan Paul.

McGregor M.C (1960), Theory X and theory Y, managementstudyguide.com/theory$\mathrm{x}-\mathrm{y}$-motivation.

Mc Guire,J \& Mc Donnell J (2008), Relationship between recreation and levels of self-determination for adolescents and young adults with disabilities, Career Development for Exceptional Individuals, 31(3).

Olowa, O.W (2012), Concept, Measurement and causes of poverty; Nigeria in perspective, American Journal of Economics, 2(1), 25-36.

Opatha, H. H. D. N. P. (2009). Human resource management. Colombo: Author publication.

Wilensky H.L \& Lebeaux C.N (1965), Industrial society and social welfare, New York, The Free Press.

Parvin, M. M. and Kabir, M. M. (2011). Factors affecting employee job satisfaction of pharmaceutical sector. Australian Journal of Business and Management Research, 1(9):113-123.

Puja, J. and Sanjeev, M. (2014). Impact of voluntary welfare measures on job satisfaction: a case study of ashok leyland india, International journal of management research and business strategy, 3(1).

Prabakar, S. (2013). Employee satisfaction \& welfare measure: a case study with special reference to Dong Bosco College of art and science. Asian pacific journal of research.

Punekar, S. D., Deodhar, S. B. and Sankaran, S. (2004). Labour welfare. Trade unionism and industrial relations. Mumbai: Himalaya Publishing House.

Reddy, K. S. (2012). Social Determinants of Cardiovascular Disease Outcomes in India. Indian Journal of Medical Research, 132(5):17-22.

Salaria, P. and Salaria, S. (2013). Employee welfare measure in auto sector. International journal of business \& management invention, 2(3):66-74.

Sathyanarayan, M. R. and Reddy R. J. (2012). A case of KCP limited. Cement industries in India, 2(7):22-29. 
Shiroma \& Jayatilake, KJHRM 2021, 16(01)

Sekaran, U. (2006). Research methods for business: a skill building approach. Wiley Indian edition.

Spector, P. E. (1997). Industrial and organization psychology. New York: John and Wiley \& son.

Tiwari, U. (2014). A study of employee welfare facilities and its impact on employee's efficiency at Vindha Telelinks Ltd, Rewa (M.P.) India, Abhinav international Monthly Refereed Journal of Research in, 3(11).

Torjman, S (2004), Culture and recreation: Links to well-being. 